\title{
Tropical and mid-latitude forcing of continental Antarctic temperatures
}

\author{
C. S. M. Turney ${ }^{1}$, C. J. Fogwill ${ }^{1}$, A. R. Klekociuk ${ }^{2,3}$, T. D. van Ommen ${ }^{2,3}$, M. A. J. Curran ${ }^{2,3}$, A. D. Moy ${ }^{2,3}$, and \\ J. G. Palmer ${ }^{1}$ \\ ${ }^{1}$ Climate Change Research Centre, School of Biological, Earth and Environmental Sciences, \\ University of New South Wales, Sydney, Australia \\ ${ }^{2}$ Australian Antarctic Division, 203 Channel Highway, Kingston 7050, Tasmania, Australia \\ ${ }^{3}$ Antarctic Climate and Ecosystems Cooperative Research Centre, University of Tasmania, \\ Private Bag 80, Hobart 7001, Tasmania, Australia
}

Correspondence to: C. S. M. Turney (c.turney@unsw.edu.au)

Received: 12 June 2015 - Published in The Cryosphere Discuss.: 30 July 2015

Revised: 27 November 2015 - Accepted: 29 November 2015 - Published: 21 December 2015

\begin{abstract}
Future changes in atmospheric circulation and associated modes of variability are a major source of uncertainty in climate projections. Nowhere is this issue more acute than across the mid-latitudes to high latitudes of the Southern Hemisphere (SH), which over the last few decades have experienced extreme and regionally variable trends in precipitation, ocean circulation and temperature, with major implications for Antarctic ice melt and surface mass balance. Unfortunately there is a relative dearth of observational data, limiting our understanding of the driving mechanism(s). Here we report a new 130-year annually resolved record of $\delta \mathrm{D}$ - a proxy for temperature - from the geographic South Pole where we find a significant influence from extratropical pressure anomalies which act as "gatekeepers" to the meridional exchange of air masses. Reanalysis of global atmospheric circulation suggests these pressure anomalies play a significant influence on mid- to high-latitude $\mathrm{SH}$ climate, modulated by the tropical Pacific Ocean. This work adds to a growing body of literature confirming the important roles of tropical and mid-latitude atmospheric circulation variability on Antarctic temperatures. Our findings suggest that future increasing tropical warmth will strengthen meridional circulation, exaggerating current trends, with potentially significant impacts on Antarctic surface mass balance.
\end{abstract}

\section{Introduction}

Uncertainty surrounding future changes in atmospheric circulation is exacerbated in the Southern Hemisphere (SH) by the acutely short baseline of observations available only since the onset of continuous monitoring during the mid-twentieth century and satellite era (post-1979) (Bracegirdle et al., 2015; Delworth and Zeng, 2014; Hobbs and Raphael, 2010; Marshall, 2003), despite the extreme and often contrasting trends in precipitation, ocean circulation and temperature (Gille, 2014), and Antarctic ice melt (Rye et al., 2014) which it has experienced in recent decades. In the high latitudes of the $\mathrm{SH}$, the limited available data suggest opposing trends over the last few decades; while the Antarctic Peninsula and West Antarctic provide strong evidence for surface warming (up to $2.5^{\circ} \mathrm{C}$ since 1950 ) (Ding et al., 2011), observations and reanalysis data have provided contrasting trends over continental East Antarctica (Jones and Lister, 2014). A potentially confounding factor is the pronounced temperature inversion that exists over much of the high-altitude plateau for most of the year (up to $10^{\circ} \mathrm{C}$ over $30 \mathrm{~m}$ ) (Hudson and Brandt, 2005), making the interpretation of surface reanalysis data problematic (Fréville et al., 2014). In marked contrast, radiosonde observations obtained through the upper atmosphere appear to provide a more robust signal, with pronounced warming observed across the mid-troposphere (centred on $650 \mathrm{hPa}$ ) during all seasons above the interior of East Antarctica, inde- 
pendent of the trends at the surface but limited to the last 5 decades (Screen and Simmonds, 2012; Turner et al., 2006).

Previous studies on Antarctic climate have suggested a significant low- and mid-latitude influence (Ding et al., 2011; Jouzel et al., 1983; Screen and Simmonds, 2012; Shaheen et al., 2013). For instance, an early study at the South Pole suggested snow $\delta \mathrm{D}$ closely mirrored the Pacific Decadal Oscillation over the previous century (Ekaykin et al., 2004). More recently, a relationship between surface temperature increases over West Antarctica, sea surface temperature (SST), and atmospheric circulation has been identified (Ding et al., 2011), implying that recent warming may be coupled to the tropical Pacific. Records extending the mid-troposphere temperature record (Screen and Simmonds, 2012; Turner et al., 2006) are therefore needed to better understand the driving mechanism(s) of warming over the continent.

Fortunately, clear-sky precipitation (or diamond dust) dominates the total precipitation over much of the continental interior (Casey et al., 2014; Ekaykin et al., 2004; Hou et al., 2007). Unlike coastal areas where different precipitation sources contribute to significant amounts of accumulation, diamond dust is continuously formed in the low atmosphere on the plateau during clear days, where most of the crystals are generated in the relatively moist upper part of the surface inversion (approximately 600-700 hPa) (Ekaykin et al., 2004; Fujita and Abe, 2006; Walden et al., 2003). During these precipitation events, thick plates/short column crystals $<150 \mu \mathrm{m}$ are commonly observed in the South Pole atmosphere (Kikuchi and Hogan, 1976, 1978; Walden et al., 2003), often producing optical effects, such as halos. Crucially, although the quantities of diamond dust can be relatively low on a daily basis (Bromwich, 1988; Massom et al., 2004), estimates suggest that over a year this type of precipitation accounts for 50 to $91 \%$ of accumulation on the plateau, including the South Pole (Casey et al., 2014; Ekaykin et al., 2004; Fujita and Abe, 2006; Hou et al., 2007). Importantly, the isotopic content of the ice crystals preserves the temperature during formation (Jones et al., 2009) in the mid-troposphere, providing a measure of conditions at the top of the inversion layer. Diamond dust on the plateau therefore offers an opportunity to investigate long-term forcing of Antarctic temperatures, supplementing radiosonde data in the region.

\section{Methods}

In January 2012 a $2 \mathrm{~m}$ snow pit was dug and contiguous snow samples were taken at $5 \mathrm{~cm}$ intervals at the geographic South Pole (Fig. 1). The snow pit was extended to $7 \mathrm{~m}$ depth by a snow core (sub-sampled at $2.5 \mathrm{~cm}$ ) obtained using a $7.5 \mathrm{~cm}$ diameter Kovacs corer (hand cored). $\delta \mathrm{D}$ analysis on the samples was undertaken on an IsoPrime mass spectrometer at the Antarctic Climate and Ecosystems Cooperative Research Centre (University of Tasmania). In addition, sodium

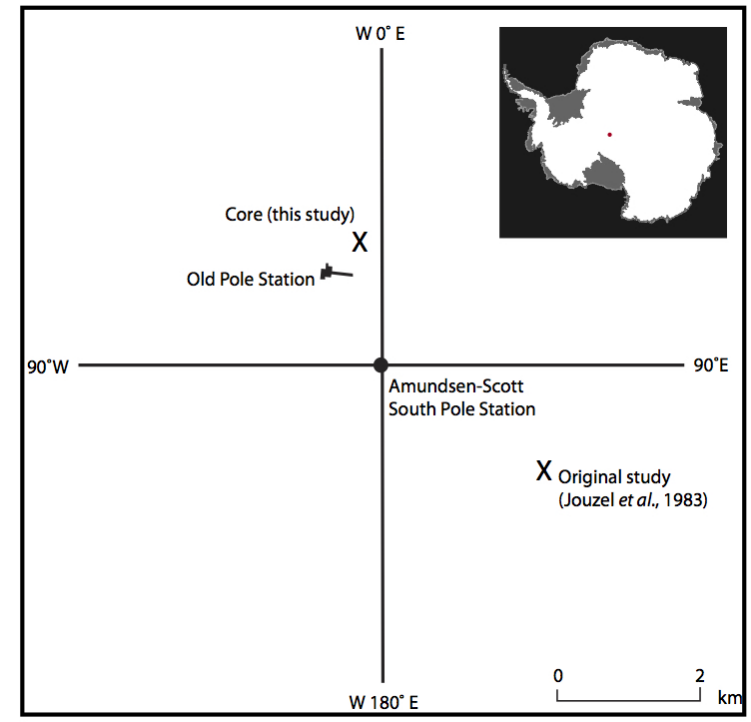

Figure 1. Location of cores investigated at the geographic South Pole.

$\left(\mathrm{Na}^{+}\right)$, magnesium $\left(\mathrm{Mg}^{2+}\right)$, non-sea salt sulfate $\left(\mathrm{nssSO} \mathrm{S}_{4}^{2-}\right)$ and methanesulfonic acid (MSA) were also measured; $\mathrm{Mg}^{2+}$ and MSA data are not shown. To develop a chronology on the core, sodium (peaking mid-winter) (Ferris et al., 2011) and $\delta \mathrm{D}$ (peaking mid-summer; taken here as January) (Jouzel et al., 1983) were used to identify annual layers (Fig. 2) using Linage in the software programme Analyseries (Paillard et al., 1996). The identification of the 1991 Mount Pinatubo and Cerro Hudson eruptions in the 1992-1993 geographic South Pole core is consistent with previous studies (Cole-Dai and Mosley-Thompson, 1999; Ferris et al., 2011).

The 2012 core overlapped with a previously reported $\delta \mathrm{D}$ sequence for the geographic South Pole across the year 1977 CE (Jouzel et al., 1983). The chronology for the older part of the sequence was based on visible stratigraphic observations, deuterium maxima, tritium and $\beta$ peaks (the latter across the 1960s and 1970s) (Jouzel et al., 1983), providing a robust chronology back to 1887 (Fig. S1 in the Supplement). To investigate multidecadal trends and reduce the impact of any missing years in the new combined South Pole record, we undertook a 30-year smoothing through the sequence.

\section{Results and discussion}

The resulting composite record of temperature-sensitive $\delta \mathrm{D}$ therefore extends the radiosonde record back before 1961 (Screen and Simmonds, 2012; Turner et al., 2006) (Fig. 3). Prior to the 1940 s we observe high inter-annual variability but with relatively stable long-term (30-year running mean) $\delta \mathrm{D}$ values, implying temperatures did not vary significantly in the mid-troposphere over this period. From the 1940s through to the 1960 s, however, we identify a trend to lower 


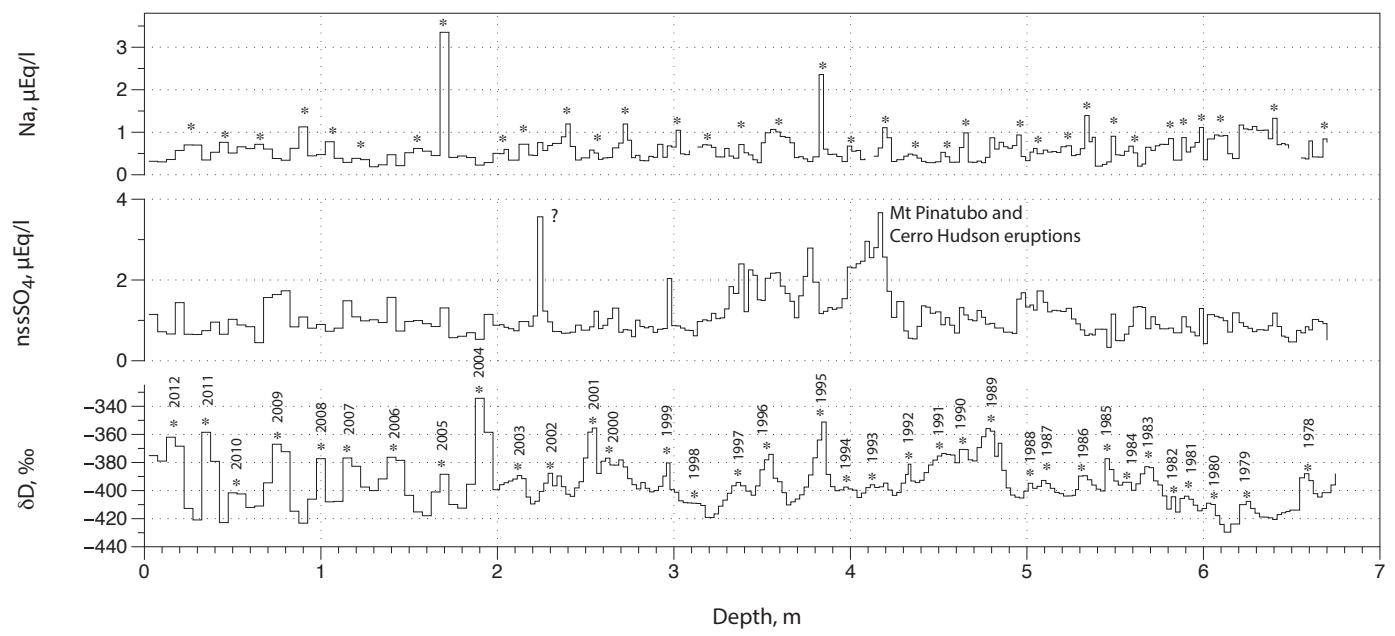

Figure 2. Annual layers identified in the geographic South Pole core obtained in January 2012. Asterisks denote peaks in sodium (Na $\left.{ }^{+}\right)$and deuterium $(\delta \mathrm{D})$, marking mid-winter and mid-summer respectively.

A.

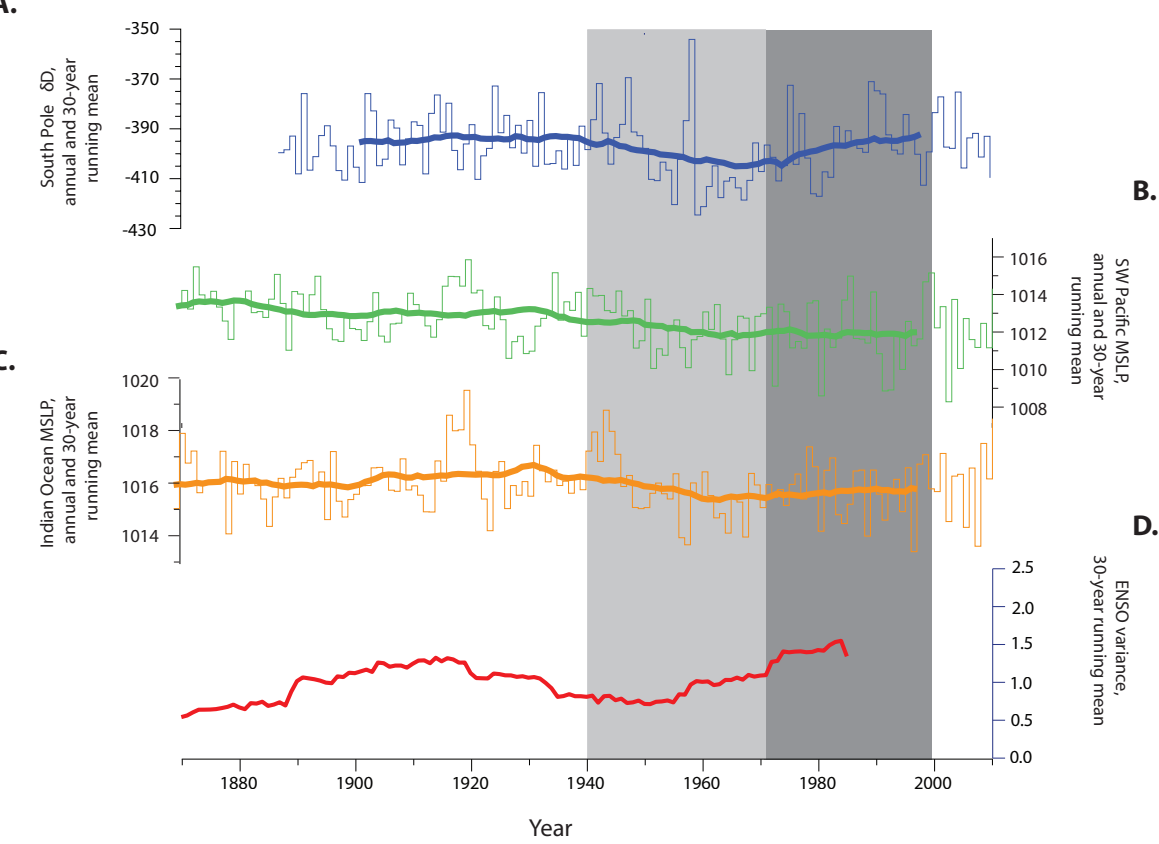

Figure 3. Annual and 30-year running mean of South Pole $\delta \mathrm{D}$ (a) compared to annual and 30-year running mean sea level pressure (hPa) for the southwestern Pacific $\left(180-160^{\circ} \mathrm{W}, 55-45^{\circ} \mathrm{S}\right)(\mathbf{b})$ and southern Indian Ocean $\left(80-100^{\circ} \mathrm{E}, 35-45^{\circ} \mathrm{S}\right)$ (c) extracted from Twentieth Century Reanalysis (Compo et al., 2011), and 30-year variance in El Niño-Southern Oscillation (McGregor et al., 2013) (d). Light grey column area denotes a period of Indian Ocean MSLP dominance over Antarctic temperatures; the dark grey column denotes the period where the southwestern Pacific MSLP is associated with warming over the geographic South Pole.

temperatures (depleted deuterium content) that was reversed in the late 1960s and apparently sustained through to present day.

To explore the potential role of SH circulation on temperatures over the geographic South Pole and the wider Antarctic continent (equatorwards of $65^{\circ} \mathrm{S}$ ), we investigated monthly average reanalysis data from ERA-Interim (Dee et al., 2011) and the Twentieth Century Reanalysis version 2 (20CR) (Compo et al., 2011) (see Supplement). For ERA-Interim, we find that on average the largest areas of significant positive temperature anomalies over the Antarctic are associated with negative surface pressure anomalies (Fig. 4a) extending up to $700 \mathrm{hPa}$ (Fig. S2) in specific regions, most notably over the southeastern Indian Ocean, southwestern Pacific (and to a 
A.

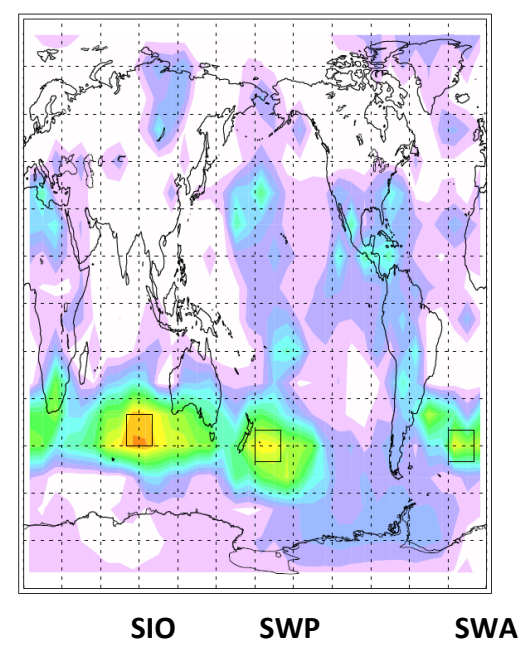

B.

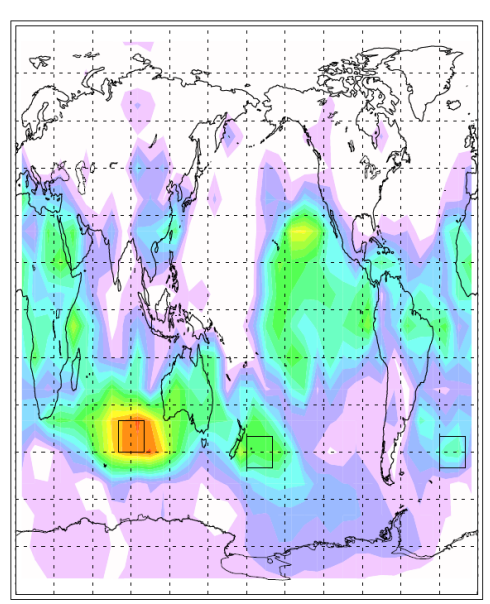

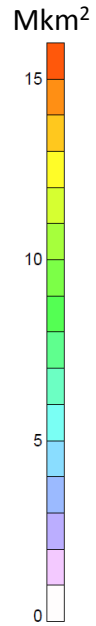

Figure 4. (a) The cumulative area of significant positive surface temperature anomalies poleward of $65^{\circ} \mathrm{S}$ (in million $\mathrm{km}^{2}$ ) produced by compositing months having negative surface pressure anomalies (thresholded at the 10th percentile) in each $10^{\circ} \times 10^{\circ}$ (longitude $\times$ latitude) box, obtained from deseasonalised monthly ERA-Interim reanalysis data for 1979-2012 (Dee et al., 2011). The three boxes define the positions referred to in the text as southern Indian Ocean (SIO), southwestern Pacific (SWP) and southwestern Atlantic (SWA). (b) shows the opposite relationship, i.e. the area of negative temperature anomalies produced by compositing months of positive surface pressure anomalies (thresholded at the 90th percentile). The grid spacing is $15^{\circ}$ in longitude and latitude. For reference, the area of the Antarctic continent is 14 million $\mathrm{km}^{2}$ and the area poleward of $65^{\circ} \mathrm{S}$ is 25 million $\mathrm{km}^{2}$.

lesser extent in the southwestern Atlantic) of the SH, and also in the eastern tropical Pacific (similar responses are also observed where comparisons are made equatorward of 55 and $75^{\circ} \mathrm{S}$; data not shown). In contrast, large areas of significant negative Antarctic temperature anomalies are associated with months of positive pressure anomalies in similar regions but have a stronger association with the southern Indian Ocean and the central-eastern equatorial Pacific (Fig. 4b); indeed the southwestern Pacific and southwestern Atlantic centres are relatively weak in this phase. There is a less pronounced connection between the Antarctic and lower latitudes in the other two anomaly combinations (temperature and pressure anomalies either both positive or both negative; Fig. S3). Patterns consistent with those shown in Figs. 4, S2 and S3 were also obtained using 20CR (not shown).

The distribution of the key southern mid-latitude centres in Fig. 4 may be related to one of several climate modes known to operate across the region. For instance, the pressure anomaly field of the Southern Annular Mode (SAM), the leading mode of climate variability of the mid-latitudes of the Southern Hemisphere, is defined as the pressure difference between around $40^{\circ} \mathrm{S}$ and the Antarctic continent $\left(65^{\circ} \mathrm{S}\right)$ (Marshall, 2003). Crucially, SAM is known to exhibit spatial and temporal asymmetry with a wave- 3 pattern in the middle latitudes (Fogt et al., 2012), which is particularly pronounced in the Pacific (Steig et al., 2009b), and has been linked to the tropics (Ding et al., 2012; Fan, 2007; Lim et al., 2013). Another possible mode of variability is the PacificSouth American (PSA) pattern, a wave train of anomalies

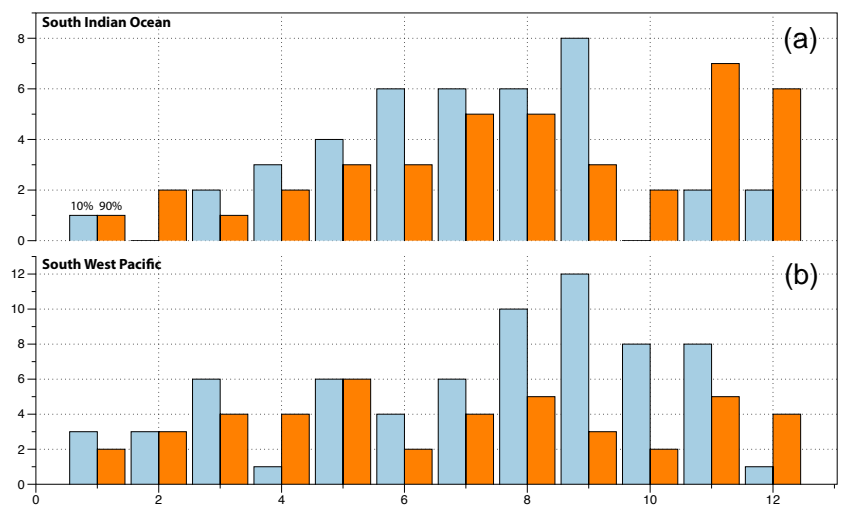

Figure 5. Distribution of 10th and 90th percentile deseasonalised surface pressure plotted for each month from 1979 to 2012 extracted from 20CR for the southern Indian (a) and southwestern Pacific (b) oceans. Note that anomalies occur throughout the year.

extending from New Zealand, off the coast of Marie Byrd Land (West Antarctica), and into the Weddell Sea-South Atlantic Ocean (Mo and Higgins, 1998) as a result of tropical forcing (Karoly, 1989). Importantly, the most positive phase of the SAM manifests itself at the surface most strongly during summer and autumn months (Thompson et al., 2011) with marked asymmetry focused on the southwestern Pacific during winter-spring (Fogt et al., 2012), while the PSA signal is primarily summer focused (Karoly, 1989). To investigate their possible role, long-term trends in sea level pressure 
A.

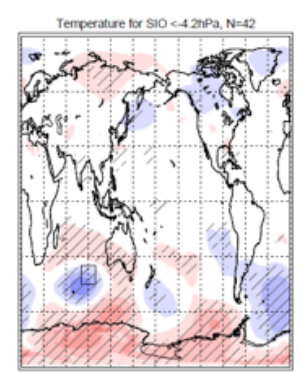

F.

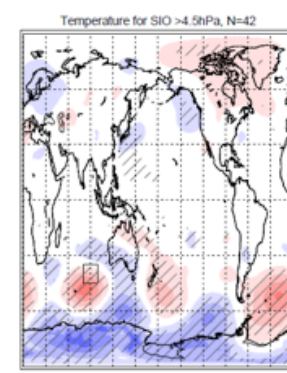

B.

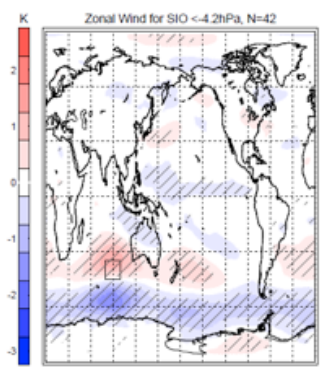

G.

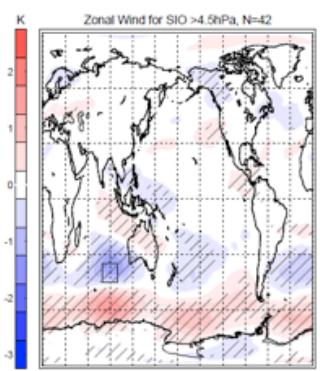

C.

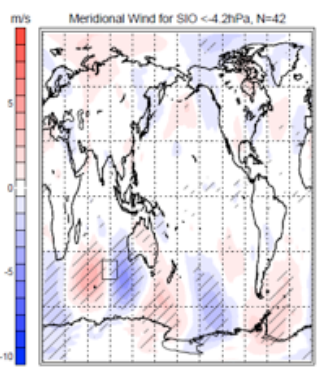

H.

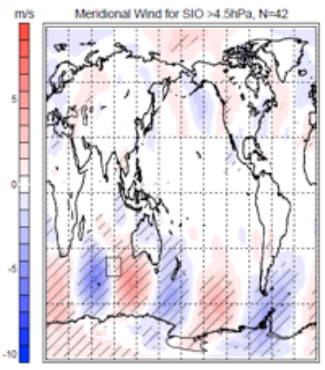

D.

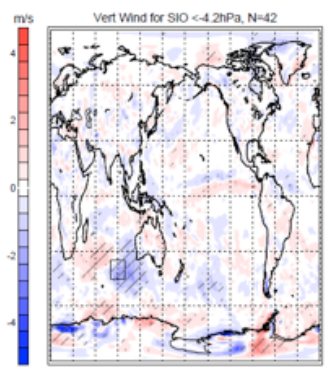

I.

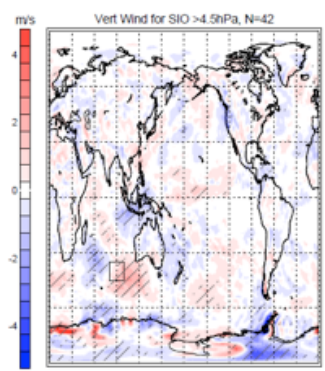

E.

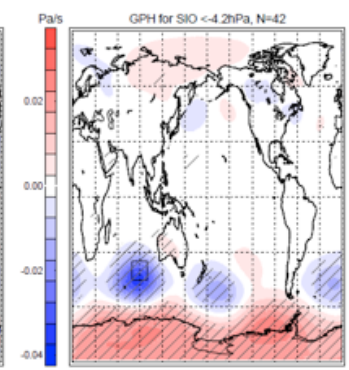

J.

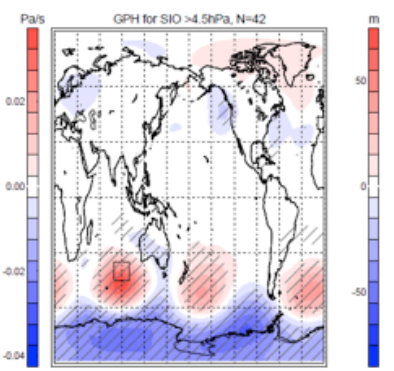

Figure 6. Composites of deseasonalised monthly ERA-Interim fields at $700 \mathrm{hPa}$ for surface pressure 10th percentile (negative) and 90th percentile (positive) anomalies in the southern Indian Ocean (SIO) $\left(80-100^{\circ}\right.$ E, 35-45 ${ }^{\circ}$ ) for 1979-2012 (Dee et al., 2011). Shown are temperature $(\mathbf{a}, \mathbf{f})$, zonal wind speed $(\mathbf{b}, \mathbf{g}$; positive $=$ eastward $)$ and meridional wind speed $(\mathbf{a}, \mathbf{f} ;$ positive $=$ northward $)$, vertical pressure wind $(\mathbf{d}, \mathbf{i}$; positive $=$ downward) and geopotential height $(\mathbf{e}, \mathbf{j})$. The SIO surface pressure anomaly threshold and the number of months $(N)$ contributing to each composite are shown along the top of each panel. Hatched areas denote areas of statistical significance (95\% confidence).

were extracted from 20CR (Compo et al., 2011). Analysis of the distribution of extremes in the 10th and 90th percentiles in the southern Indian Ocean and southwestern Pacific deseasonalised mean sea level pressure (MSLP) (1979 to present day) indicates the distribution of anomalies is across the year and not skewed to a particular month or season (Fig. 5) suggesting SAM or PSA does not account for the observed anomalies.

Alternatively, the low-pressure anomalies associated here with warming over the geographic South Pole and wider Antarctica may be linked to the zonal wave-3 pattern (ZW3) (Raphael, 2004), which plays a significant role in meridional flow across $45-55^{\circ} \mathrm{S}$ on interannual to decadal timescales (Steig et al., 2009a). ZW3 has been associated with changing sea ice concentration in the Southern Ocean (Raphael, 2007), the delivery of rainfall to southwestern Australia (van Ommen and Morgan, 2010) and recent warming over West Antarctica (Steig et al., 2009a). Estimates obtained across the period of satellite observations (post-1979) suggest ZW3 explains some $8 \%$ of SH circulation but hemispherically averaged reconstructions only extend back to the 1960s (Raphael, 2004), hampering our understanding of its significance on multi-decadal timescales. Long-term changes in ZW3 and its influence on the SH remain highly uncertain, with limited observational data in a marine-dominated realm. Recent work has suggested ZW3 provides a mechanism for the meridional exchange of air masses, implying a strengthening since the 1970s (Schneider et al., 2004; van Ommen and Morgan, 2010), a trend coupled models struggle to reproduce (Holland and Raphael, 2006; Landrum et al., 2012; Steig et al., 2009a).

We observe fields at $700 \mathrm{hPa}$ composited for 10th percentile (negative) surface pressure anomalies in the southeastern Indian Ocean (panels a-e of Figs. 6 and S4) and southwestern Pacific Ocean (panels a-e of Figs. 7 and S5) are associated with contrasting meridional airflow direction across the SH mid-latitudes (including enhanced northerly airflow extending over southwestern Australia, consistent with regional precipitation decline over the past few decades) (Delworth and Zeng, 2014) and an increase in geopotential height (GPH) over the Antarctic continent. Both the ERA (Figs. 6 and 7) and 20CR (Figs. S4 and S5) generate similar patterns, providing confidence that large-scale processes are being appropriately captured. By examining the meridional mass streamfunction (Fig. 8), we find that in comparison with the situation in the intermediate state, the negative anomaly state shows a weakening (reduced volume) of the polar cell and a strengthening (increased volume) of the Ferrel cell (particularly on the poleward side of the cell), consistent with increased poleward heat transport. In marked contrast, the opposite pattern is observed with positive pressure anomalies in the mid-latitudes, with a stronger polar cell (particularly with the SIO region) and weaker Ferrel cell (also seen 
A.

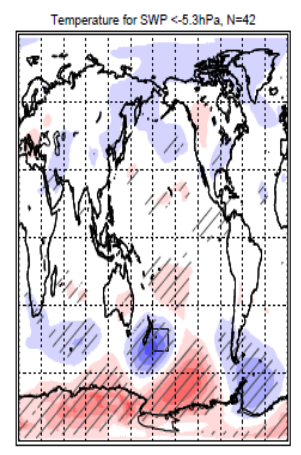

F.

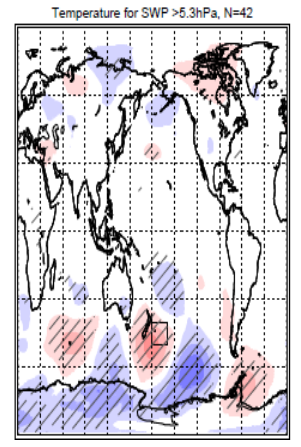

B.

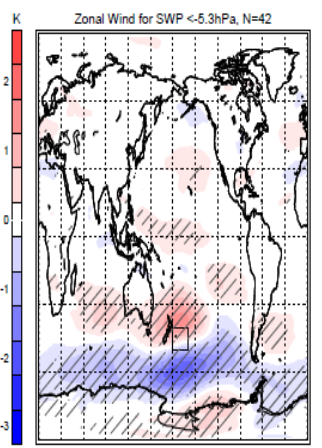

G.

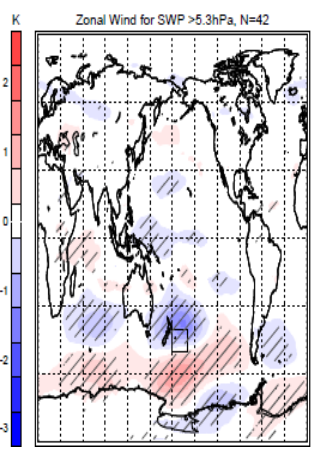

C.

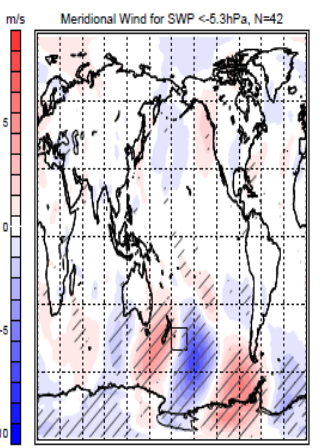

H.

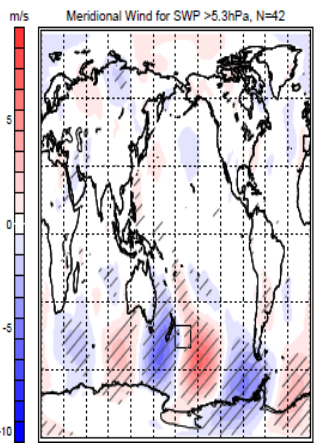

D.

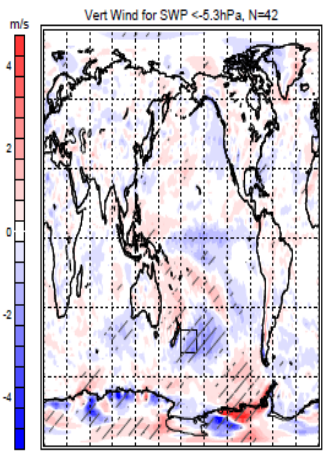

I.

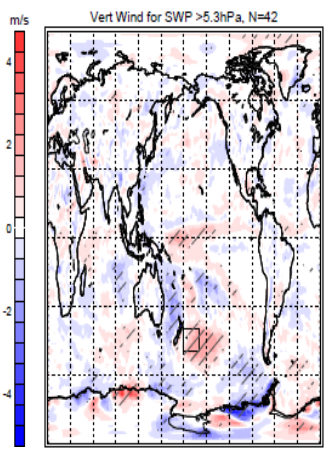

E.

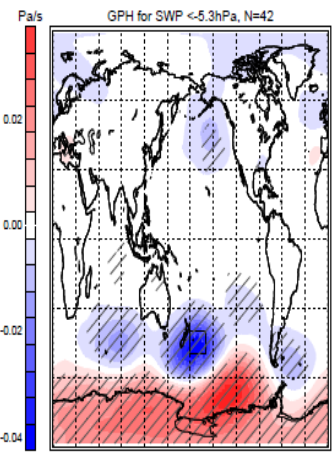

J.

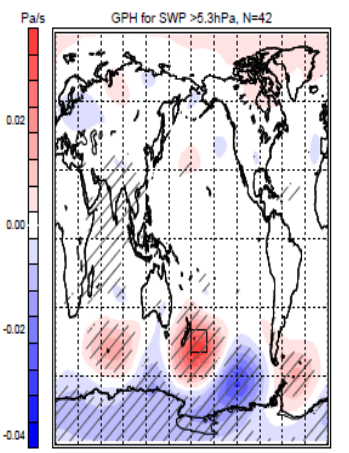

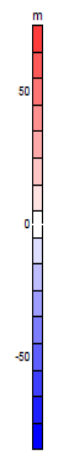

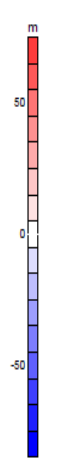

Figure 7. Composites of deseasonalised monthly ERA-Interim reanalysis fields at $700 \mathrm{hPa}$ for surface pressure 10th percentile (negative) and 90th percentile (positive) anomalies in the southwestern Pacific (SWP) Ocean (180-200 E, 45-55 ${ }^{\circ}$ S) for 1979-2012 (Dee et al., 2011). Shown are temperature $(\mathbf{a}, \mathbf{f})$, zonal wind speed $(\mathbf{b}, \mathbf{g} ;$ positive $=$ eastward $)$ and meridional wind speed $(\mathbf{c}, \mathbf{h} ;$ positive $=$ northward $)$, vertical pressure wind (d, i; positive $=$ downward) and geopotential height $(\mathbf{e}, \mathbf{j})$. The SWP surface pressure anomaly threshold and the number of months $(N)$ contributing to each composite are shown at the top of each panel. Hatched areas denote areas of statistical significance $(95 \%$ confidence).

in the SWP), suggesting a greater dynamical barrier to poleward heat transport.

To explore whether this relationship has changed over annual to decadal timescales (during the pre-satellite era), we undertook wavelet coherence analysis between annually resolved Pacific and Indian Ocean pressure anomalies as extracted from the 20CR with our newly obtained geographic South Pole $\delta$ D record (Fig. 9). Focusing on the second half of the twentieth century (considered to have more reliable reconstructive ability over the mid-latitudes of the $\mathrm{SH}$ ) (Compo et al., 2011), we observe a significant shift in the dominance of the different pressure anomalies. During the 1940s through to the early 1960s, pressure anomalies centred on the southern Indian Ocean share common periodicities across 48 years, paralleling the 30-year trend (Fig. 3); in the southwestern Pacific, the common periodicity is less strongly expressed over the same time period. During the late 1980s, a similar multiyear coherence appears to have re-established between the southwestern Pacific and South Pole across 416 years (albeit the most recent period falling within the cone of influence), with limited evidence for a teleconnection between the southern Indian Ocean and Antarctica (Fig. 9). Fur- ther work is now required to extend the observational record of the mid-latitudes beyond the mid-1940s.

Intriguingly, the periodicities (Fig. 9) and spatial plots of pressure anomalies versus Antarctic temperature (Fig. 4) suggest the tropical Pacific may play a role. Teleconnections have been observed between SH low and mid- to high latitudes (Bromwich et al., 2000; Ding et al., 2011; Turner, 2004; Vance et al., 2012), but different seasonal teleconnections have been reported, including central Pacific temperature changes in the austral winter (Ding et al., 2011), linear forcing between the El Niño-Southern Oscillation (ENSO) and SAM in the austral summer (Fan, 2007; L'Heureux and Thompson, 2006) and changing teleconnections depending on the relative phasing of different modes (Clem and Fogt, 2015; Stammerjohn et al., 2008).

Here we find no significant relationship between the southwestern Pacific pressure anomaly and annual average GPH in the tropical western Pacific (Fig. 7), while absolute differences in the tropics are relatively small (Fig. 8). These, however, may be masked by seasonal changes. To investigate this more fully, we undertook seasonal correlations between changes in southwestern Pacific pressure, mean sea 
A.
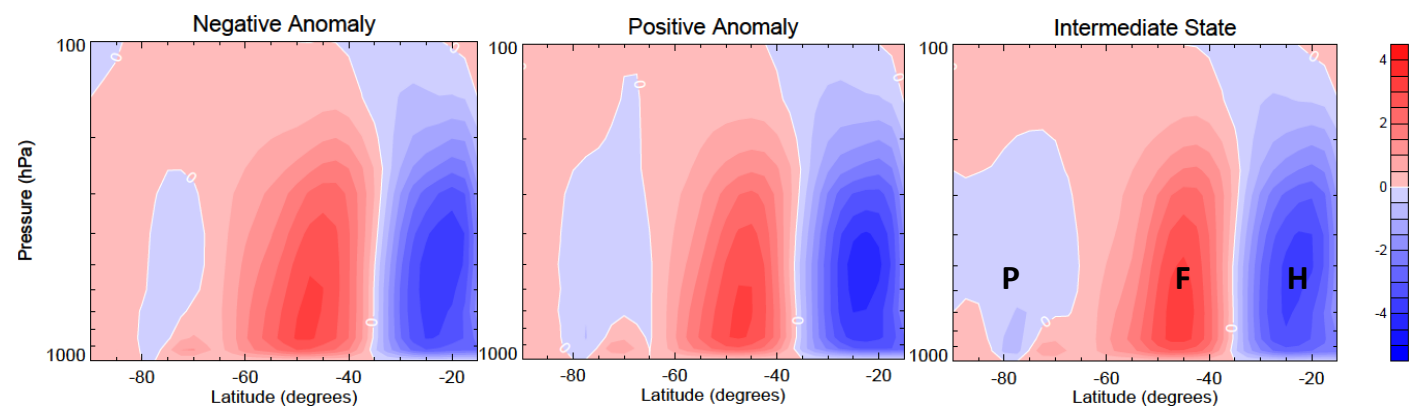

B.
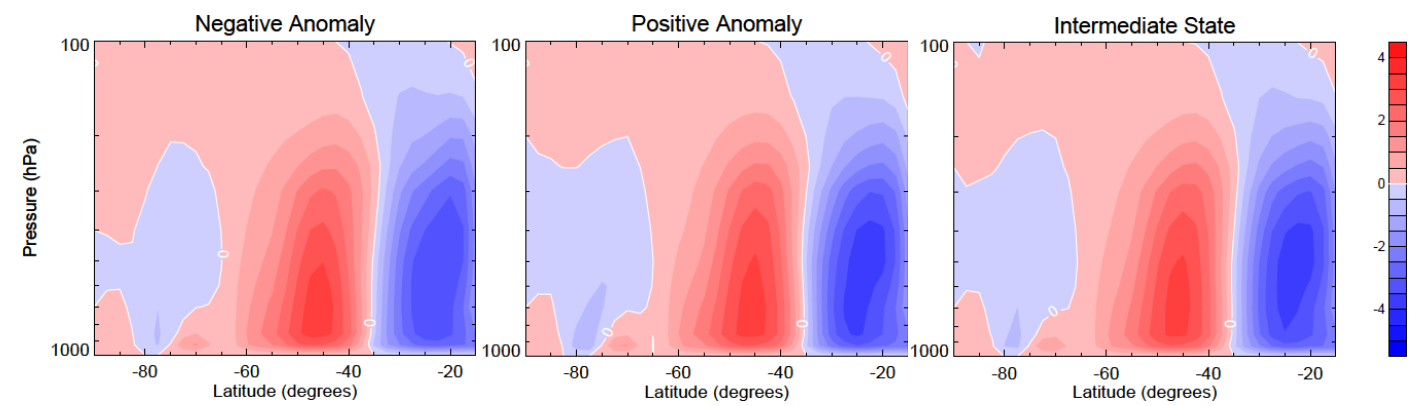

Figure 8. The deseasonalised mean meridional mass streamfunction obtained from daily mean NCEP/NCAR reanalysis (1979-2012) (Kalnay et al., 1996). Shown left to right are composites for negative, positive and intermediate monthly surface pressure anomalies in the SIO region (a) and SWP region (b). Positive (negative) values denote clockwise (anticlockwise) rotation in the plane of the figure; the Hadley, Ferrel and polar cells are marked H, F and P, respectively. The units are $10^{10} \mathrm{~kg} \mathrm{~s}^{-1}$.

A.

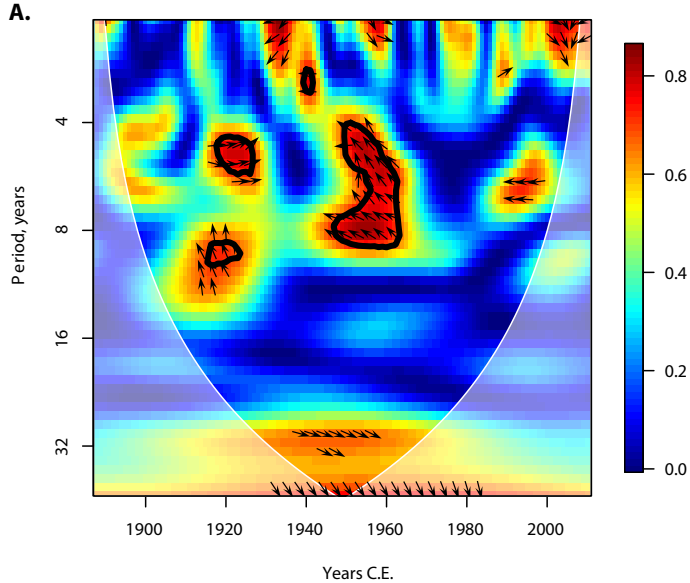

B.

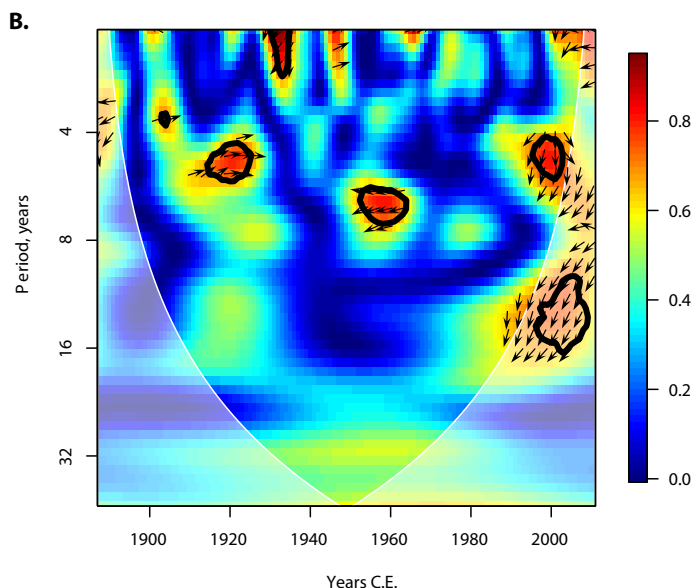

Figure 9. Wavelet coherence plots between annually resolved geographic South Pole $\delta \mathrm{D}$ and the SIO (a) and SWP (b) surface pressure extracted from the 20CR (Compo et al., 2011). Major periodicities (95\% confidence) are defined by solid black contours; the white dashed lines denote the cone of influence. Arrows indicate relative phase with angle measured anticlockwise from in-phase (pointing to the right) through SIO and SWP pressure leading South Pole $\delta \mathrm{D}$ (temperature) in quadrature (pointing upwards) to anti-phase (pointing left).

level pressure and sea surface temperatures across the period 1979-2013 (Fig. 10). We observe a significant inverse relationship with the tropical western Pacific between September and May but no significant correlation during the austral winter (June to August). Specifically, we find low pressure over the southwestern Pacific is associated with the centres of low pressure in the southern Indian Ocean and the southwestern Atlantic Ocean, high temperatures in the Amundsen Sea and the central and east tropical Pacific, and relatively high pressure over the tropical western Pacific (Fig. 10). Whilst the opposing relationship between the southwestern Pacific pressures and the West Antarctic (Marie Byrd Land) is observed, this does not extend into the mid-latitudes of the South Atlantic, supporting the conclusion we are not observing a PSA pattern (Mo and Higgins, 1998). Instead, the seasonal and geographical nature of this relationship is consistent with a 

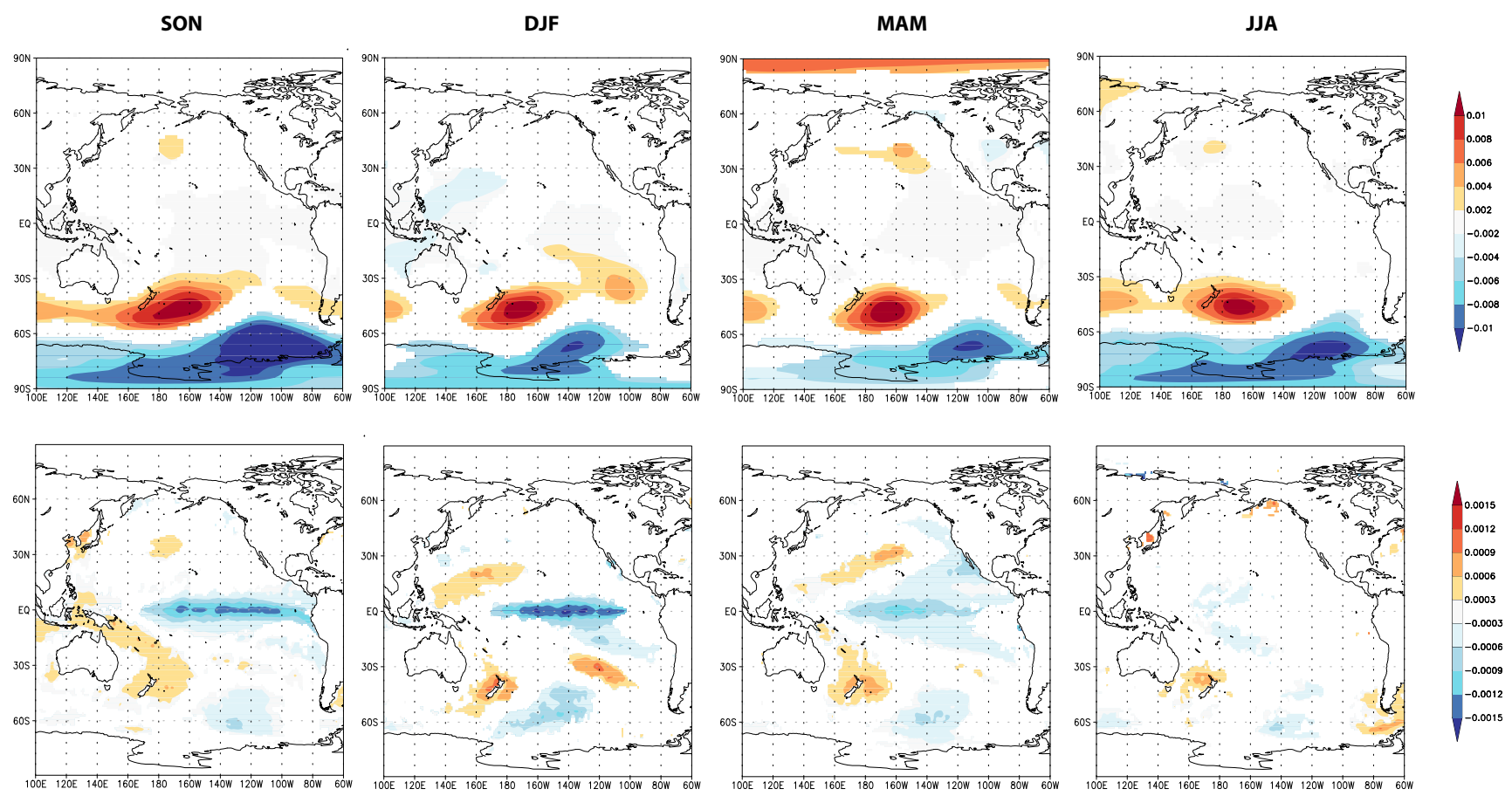

Figure 10. Contoured regressions between detrended and deseasonalised southwestern Pacific (SWP) sea level pressure and Pacific-wide 20CR sea level pressure (a-d) (Compo et al., 2011), and sea surface temperatures (SSTs) (e-j) (Rayner et al., 2003) (1979-2013) during September-November (SON), December-February (DJF), March-May (MAM) and June-August (JJA). Significance $p_{\text {field }}<0.1 \%$. Analyses were made with KNMI Climate Explorer (van Oldenborgh and Burgers, 2005). Note the significant inverse relationship between SWP, tropical western Pacific sea level pressure and central and east tropical Pacific SSTs during September-November, December-February and March-May (but not June-August), a region and seasons closely associated with tropical Pacific variability (Collins et al., 2010).

tropical central and east Pacific modulation of Antarctic temperatures, delivered via the southwestern Pacific.

Importantly, the relationship between the tropical Pacific and the pressure anomalies recognised here is only observed during individual months (i.e. in isolation) and is not exhibited during consecutive months associated with extreme ENSO events. Furthermore, we do not observe substantial warming over the South Pole during the period of increased ENSO variance in the early twentieth century (Fig. 3). Our data therefore suggest there is a tropical east Pacific role (particularly with positive pressure anomalies - akin to stronger Walker cell circulation) - but that this may only have a modulating effect and is not the driver of variability. Intriguingly, recent work has demonstrated a late twentieth century trend towards a cooler tropical east Pacific and stronger Walker cell circulation (England et al., 2014; Karnauskas et al., 2009; L'Heureux et al., 2013) with potentially confounding effects on temperature trends over the Antarctic (Clem and Fogt, 2015). Our data are consistent with such studies. The recent trend towards a stronger Walker cell circulation (and trade winds) has an opposing relationship to Antarctic temperatures (Fig. 4), suggesting any decrease in atmospheric pressure in the southwestern Pacific may be partially cancelled out by an atmospheric Rossby wave response generated in the tropical Pacific, as observed across the Antarctic Penin- sula and West Antarctic (Clem and Fogt, 2015). With projected weakening of the trade winds (England et al., 2014), the observed links to Antarctic temperatures suggest the tropics may in fact play an increasingly significant role in driving high-latitude warming (Figs. 4 and 10), with potentially important implications for understanding past climate states (McGlone et al., 2010; Pedro et al., 2011; Visser et al., 2003) and future Antarctic surface mass balance.

\section{Conclusions}

By extending historical observations over the South Pole and in combination with reanalysis products, we find that meridional circulation changes associated with centres of pressure anomalies are part of a broader change observed over recent decades. Of particular note is the marked decrease in rainfall in southwestern Australia since the 1970s. Our results demonstrate this trend is part of a hemispheric pattern of alternating northerly and southerly airflow linked to changes in the southwestern Pacific and the tropical Pacific. We explore teleconnections via a strengthening of the Ferrel cell and a weakening polar cell, possibly associated with zonal wave3 (ZW3) circulation. Comparison of 30-year running means of isotopic and climate data sets suggests the long-term low- 
pressure anomalies in the southwestern Pacific - with largely stable values in the Indian Ocean - are modulated by lowlatitude change. Our findings imply that future increasing tropical warmth will strengthen meridional circulation across the mid-latitudes, exaggerating current trends, with potentially significant impacts on Antarctic surface mass balance.

\section{The Supplement related to this article is available online at doi:10.5194/tc-9-2405-2015-supplement.}

Acknowledgements. The authors thank the Australian Research Council for their financial support (FL100100195; LP120200724, DP130104156 and FT120100004). We are extremely grateful to the support in the field provided by Antarctic Logistics and Expeditions (ALE), who made this work possible. Many thanks to J. Jouzel for providing the data from previous work at South Pole and Eleanor Rainsley for comments on an earlier draft of the manuscript. The NOAA-CIRES Twentieth Century Reanalysis Project version 2 used resources of the National Energy Research Scientific Computing Center managed by Lawrence Berkeley National Laboratory, which is supported by the Office of Science of the US Department of Energy under contract no. DE-AC02-05CH11231. Support for the Twentieth Century Reanalysis Project version 2 data set is provided by the US Department of Energy, Office of Science Biological and Environmental Research (BER), and by the National Oceanic and Atmospheric Administration Climate Program Office. We thank R. Fogt and an anonymous reviewer for their constructive comments.

Edited by: M. van den Broeke

\section{References}

Bracegirdle, T., Bertler, N., Carleton, A., Ding, Q., Fogwill, C., Fyfe, J., Hellmer, H., Karpechko, A., Kusahara, K., and Larour, E.: A multi-disciplinary perspective on climate model evaluation for Antarctica, B. Am. Meteorol. Soc., doi:10.1175/BAMS-D15-00108.1, online first, 2015.

Bromwich, D.: Snowfall in high southern latitudes, Rev. Geophys., 26, 149-168, 1988.

Bromwich, D. H., Rogers, A. N., Kållberg, P., Cullather, R. I., White, J. W. C., and Kreutz, K. J.: ECMWF analyses and reanalyses depiction of ENSO signal in Antarctic precipitation, J. Climate, 13, 1406-1420, 2000.

Casey, K., Fudge, T., Neumann, T., Steig, E., Cavitte, M., and Blankenship, D.: The $1500 \mathrm{~m}$ South Pole ice core: recovering a 40 ka environmental record, Ann. Glaciol., 55, 137-146, 2014.

Clem, K. R. and Fogt, R. L.: South Pacific circulation changes and their connection to the tropics and regional Antarctic warming in austral spring, 1979-2012, J. Geophys. Res.-Atmos., 120, 27732792, 2015.

Cole-Dai, J. and Mosley-Thompson, E.: The Pinatubo eruption in South Pole snow and its potential value to ice-core paleovolcanic records, Ann. Glaciol., 29, 99-105, 1999.
Collins, M., An, S.-I., Cai, W., Ganachaud, A., Guilyardi, E., Jin, F.-F., Jochum, M., Lengaigne, M., Power, S., Timmermann, A., Vecchi, G., and Wittenberg, A.: The impact of global warming on the tropical Pacific Ocean and El Nino, Nat. Geosci., 3, 391-397, 2010.

Compo, G. P., Whitaker, J. S., Sardeshmukh, P. D., Matsui, N., Allan, R. J., Yin, X., Gleason, B. E., Vose, R. S., Rutledge, G., Bessemoulin, P., Brönnimann, S., Brunet, M., Crouthamel, R. I., Grant, A. N., Groisman, P. Y., Jones, P. D., Kruk, M. C., Kruger, A. C., Marshall, G. J., Maugeri, M., Mok, H. Y., Nordli, Ø., Ross, T. F., Trigo, R. M., Wang, X. L., Woodruff, S. D., and Worley, S. J.: The Twentieth Century Reanalysis Project, Q. J. Roy. Meteor. Soc., 137, 1-28, 2011.

Dee, D. P., Uppala, S. M., Simmons, A. J., Berrisford, P., Poli, P., Kobayashi, S., Andrae, U., Balmaseda, M. A., Balsamo, G., Bauer, P., Bechtold, P., Beljaars, A. C. M., van de Berg, L., Bidlot, J., Bormann, N., Delsol, C., Dragani, R., Fuentes, M., Geer, A. J., Haimberger, L., Healy, S. B., Hersbach, H., Hólm, E. V., Isaksen, L., Kållberg, P., Köhler, M., Matricardi, M., McNally, A. P., Monge-Sanz, B. M., Morcrette, J. J., Park, B. K., Peubey, C., de Rosnay, P., Tavolato, C., Thépaut, J. N., and Vitart, F.: The ERA-Interim reanalysis: configuration and performance of the data assimilation system, Q. J. Roy. Meteor. Soc., 137, 553-597, 2011.

Delworth, T. L. and Zeng, F.: Regional rainfall decline in Australia attributed to anthropogenic greenhouse gases and ozone levels, Nat. Geosci., 7, 583-587, 2014.

Ding, Q., Steig, E. J., Battisti, D. S., and Kuttel, M.: Winter warming in West Antarctica caused by central tropical Pacific warming, Nat. Geosci., 4, 398-403, 2011.

Ding, Q., Steig, E. J., Battisti, D. S., and Wallace, J. M.: Influence of the tropics on the Southern Annular Mode, J. Climate, 25, 6330 6348, 2012.

Ekaykin, A. A., Lipenkov, V. Y. a., Kuzmina, I. N., Petit, J. R., Masson-Delmotte, V., and Johnsen, S. J.: The changes in isotope composition and accumulation of snow at Vostok station, East Antarctica, over the past 200 years, Ann. Glaciol., 39, 569-575, 2004.

England, M. H., McGregor, S., Spence, P., Meehl, G. A., Timmermann, A., Cai, W., Gupta, A. S., McPhaden, M. J., Purich, A., and Santoso, A.: Recent intensification of wind-driven circulation in the Pacific and the ongoing warming hiatus, Nature Climate Change, 4, 222-227, 2014.

Fan, K.: Zonal asymmetry of the Antarctic Oscillation, Geophys. Res. Lett., 34, L02706, doi:10.1029/2006GL028045, 2007.

Ferris, D. G., Cole-Dai, J., Reyes, A. R., and Budner, D. M.: South Pole ice core record of explosive volcanic eruptions in the first and second millennia A.D. and evidence of a large eruption in the tropics around 535 A.D., J. Geophys. Res., 116, D17308, doi:10.1029/2011JD015916, 2011.

Fogt, R. L., Jones, J. M., and Renwick, J.: Seasonal zonal asymmetries in the Southern Annular Mode and their impact on regional temperature anomalies, J. Climate, 25, 6253-6270, 2012.

Fréville, H., Brun, E., Picard, G., Tatarinova, N., Arnaud, L., Lanconelli, C., Reijmer, C., and van den Broeke, M.: Using MODIS land surface temperatures and the Crocus snow model to understand the warm bias of ERA-Interim reanalyses at the surface in Antarctica, The Cryosphere, 8, 1361-1373, doi:10.5194/tc-81361-2014, 2014. 
Fujita, K. and Abe, O.: Stable isotopes in daily precipitation at Dome Fuji, East Antarctica, Geophys. Res. Lett., 33, L18503, doi:10.1029/2006GL026936, 2006.

Gille, S. T.: Meridional displacement of the Antarctic Circumpolar Current, Philos. T. R. Soc. A, 372, doi:10.1098/rsta.2013.0273, 2014.

Hobbs, W. and Raphael, M.: Characterizing the zonally asymmetric component of the SH circulation, Clim. Dynam., 35, 859-873, 2010.

Holland, M. and Raphael, M.: Twentieth century simulation of the southern hemisphere climate in coupled models. Part II: sea ice conditions and variability, Clim. Dynam., 26, 229-245, 2006.

Hou, S., Li, Y., Xiao, C., and Ren, J.: Recent accumulation rate at Dome A, Antarctica, Chinese Sci. Bull., 52, 428-431, 2007.

Hudson, S. R. and Brandt, R. E.: A look at the surface-based temperature inversion on the Antarctic Plateau, J. Climate, 18, 16731696, 2005.

Jones, P. D., Briffa, K. R., Osborn, T. J., Lough, J. M., van Ommen, T. D., Vinther, B. M., Luterbacher, J., Wahl, E. R., Zwiers, F. W., Mann, M. E., Schmidt, G. A., Ammann, C. M., Buckley, B. M., Cobb, K. M., Esper, J., Goosse, H., Graham, N., Jansen, E., Kiefer, T., Kull, C., Küttel, M., Mosley-Thompson, E., Overpeck, J. T., Riedwyl, N., Schulz, M., Tudhope, A. W., Villalba, R., Wanner, H., Wolff, E., and Xoplaki, E.: High-resolution palaeoclimatology of the last millennium: A review of current status and future prospects, The Holocene, 19, 3-49, 2009.

Jones, P. D. and Lister, D. H.: Antarctic near-surface air temperatures compared with ERA-Interim values since 1979, Int. J. Climatol., 35, 1354-1366, doi:10.1002/joc.4061, 2014.

Jouzel, J., Merlivat, L., Petit, J. R., and Lorius, C.: Climatic information over the last century deduced from a detailed isotopic record in the South Pole snow, J. Geophys. Res., 88, 2693-2703, 1983.

Kalnay, E., Kanamitsu, M., Kistler, R., Collins, W., Deaven, D., Gandin, L., Iredell, M., Saha, S., White, G., Woollen, J., Zhu, Y., Leetmaa, A., Reynolds, R., Chelliah, M., Ebisuzaki, W., Higgins, W., Janowiak, J., Mo, K. C., Ropelewski, C., Wang, J., Jenne, R., and Joseph, D.: The NCEP/NCAR 40-year reanalysis project, B. Am. Meteorol. Soc., 77, 437-471, 1996.

Karnauskas, K. B., Seager, R., Kaplan, A., Kushnir, Y., and Cane, M. A.: Observed strengthening of the zonal sea surface temperature gradient across the equatorial Pacific Ocean, J. Climate, 22, 4316-4321, 2009.

Karoly, D. J.: Southern Hemisphere circulation features associated with El Niño-Southern Oscillation events, J. Climate, 2, 12391252, 1989.

Kikuchi, K. and Hogan, A. W.: Snow crystal observations in summer season at Amundsen-Scott South Pole Station, Antarctica, Journal of the Faculty of Science, Hokkaido University, Series 7 , Geophysics 5, 1-20, 1976.

Kikuchi, K. and Hogan, A. W.: Properties of diamond dust type ice crystals observed in summer season at Amundsen-Scott South Pole Station, Antarctica, Journal of Meteorological Society of Japan, 57, 180-189, 1978.

Landrum, L., Holland, M. M., Schneider, D. P., and Hunke, E.: Antarctic sea ice climatology, variability, and late TwentiethCentury change in CCSM4, J. Climate, 25, 4817-4838, 2012.
L'Heureux, M. L. and Thompson, D. W.: Observed relationships between the El Niño-Southern Oscillation and the extratropical zonal-mean circulation, J. Climate, 19, 276-287, 2006.

L'Heureux, M. L., Lee, S., and Lyon, B.: Recent multidecadal strengthening of the Walker circulation across the tropical Pacific, Nature Climate Change, 3, 571-576, 2013.

Lim, E.-P., Hendon, H. H., and Rashid, H.: Seasonal predictability of the Southern Annular Mode due to Its association with ENSO, J. Climate, 26, 8037-8054, 2013.

Marshall, G.: Trends in the Southern Annular Mode from observations and reanalyses, J. Climate, 16, 4134-4143, 2003.

Massom, R. A., Pook, M. J., Comiso, J. C., Adams, N., Turner, J., Lachlan-Cope, T., and Gibson, T. T.: Precipitation over the interior East Antarctic Ice Sheet related to midlatitude blockinghigh activity, J. Climate, 17, 1914-1928, 2004.

McGlone, M. S., Turney, C. S. M., Wilmshurst, J. M., and Pahnke, K.: Divergent trends in land and ocean temperature in the Southern Ocean over the past 18,000 years, Nat. Geosci., 3, 622-626, 2010.

McGregor, S., Timmermann, A., England, M. H., Elison Timm, O., and Wittenberg, A. T.: Inferred changes in El Niño-Southern Oscillation variance over the past six centuries, Clim. Past, 9, 22692284, 2013, http://www.clim-past.net/9/2269/2013/.

Mo, K. C. and Higgins, R. W.: The Pacific-South American modes and tropical convection during the Southern Hemisphere winter, Monthly Weather Review, 126, 1581-1596, 1998.

Paillard, D., Labeyrie, L., and Yiou , P.: Macintosh program performs time-series analysis, Eos, 77, p. 379, 1996.

Pedro, J. B., van Ommen, T. D., Rasmussen, S. O., Morgan, V. I., Chappellaz, J., Moy, A. D., Masson-Delmotte, V., and Delmotte, M.: The last deglaciation: timing the bipolar seesaw, Clim. Past, 7, 671-683, doi:10.5194/cp-7-671-2011, 2011.

Raphael, M. N.: A zonal wave 3 index for the Southern Hemisphere, Geophys. Res. Lett., 31, L23212, doi:10.1029/2004GL020365, 2004.

Raphael, M. N.: The influence of atmospheric zonal wave three on Antarctic sea ice variability, J. Geophys. Res.-Atmos., 112, D12112, doi:10.1029/2006JD007852, 2007.

Rayner, N. A., Parker, D. E., Horton, E. B., Folland, C. K., Alexander, L. V., Rowell, D. P., Kent, E. C., and Kaplan, A.: Global analyses of sea surface temperature, sea ice, and night marine air temperature since the late nineteenth century, J. Geophys. Res.Atmos., 108, 4407, doi:10.1029/2002JD002670, 2003.

Rye, C. D., Naveira Garabato, A. C., Holland, P. R., Meredith, M. P., George Nurser, A. J., Hughes, C. W., Coward, A. C., and Webb, D. J.: Rapid sea-level rise along the Antarctic margins in response to increased glacial discharge, Nat. Geosci., 7, 732735, 2014.

Schneider, D. P., Steig, E. J., and Comiso, J. C.: Recent climate variability in Antarctica from satellite-derived temperature data, J. Climate, 17, 1569-1583, 2004.

Screen, J. A. and Simmonds, I.: Half-century air temperature change above Antarctica: Observed trends and spatial reconstructions, J. Geophys. Res.-Atmos., 117, D16108, doi:10.1029/2012JD017885, 2012.

Shaheen, R., Abauanza, M., Jackson, T. L., McCabe, J., Savarino, J., and Thiemens, M. H.: Tales of volcanoes and El-Niño southern oscillations with the oxygen isotope anomaly of 
sulfate aerosol, P. Natl. A. Sci. USA, 110, 17662-17667, doi:10.1073/pnas.1213149110, 2013.

Stammerjohn, S. E., Martinson, D. G., Smith, R. C., Yuan, X., and Rind, D.: Trends in Antarctic annual sea ice retreat and advance and their relation to El Niño-Southern Oscillation and Southern Annular Mode variability, J. Geophys. Res.-Oceans, 113, C03S90, doi:10.1029/2007JC004269, 2008.

Steig, E. J., Schneider, D. P., Rutherford, S. D., Mann, M. E., Comiso, J. C., and Shindell, D. T.: Warming of the Antarctic ice-sheet surface since the 1957 International Geophysical Year, Nature, 457, 459-462, 2009a.

Steig, E. J., Schneider, D. P., Rutherford, S. D., Mann, M. E., Comiso, J. C., and Shindell, D. T.: Warming of the Antarctic ice-sheet surface since the 1957 International Geophysical Year, Nature, 457, 459-462, 2009b.

Thompson, D. W. J., Solomon, S., Kushner, P. J., England, M. H., Grise, K. M., and Karoly, D. J.: Signatures of the Antarctic ozone hole in Southern Hemisphere surface climate change, Nat. Geosci., 4, 741-749, 2011.

Turner, J.: The El Niño-Southern Oscillation and Antarctica, Int. J. Climatol., 24, 1-31, 2004.
Turner, J., Lachlan-Cope, T. A., Colwell, S., Marshall, G. J., and Connolley, W. M.: Significant warming of the Antarctic winter troposphere, Science, 311, 1914-1917, 2006.

Vance, T. R., van Ommen, T. D., Curran, M. A. J., Plummer, C. T., and Moy, A. D.: A millennial proxy record of ENSO and eastern Australian rainfall from the Law Dome ice core, East Antarctica, J. Climate, 26, 710-725, 2012.

van Oldenborgh, G. J. and Burgers, G.: Searching for decadal variations in ENSO precipitation teleconnections, Geophys. Res. Lett., 32, L15701, doi:10.1029/2005GL023110, 2005.

van Ommen, T. D. and Morgan, V.: Snowfall increase in coastal East Antarctica linked with southwest Western Australian drought, Nat. Geosci., 3, 267-272, 2010.

Visser, K., Thunell, R., and Stott, L.: Magnitude and timing of temperature change in the Indo-Pacific warm pool during deglaciation, Nature, 421, 152-155, 2003.

Walden, V. P., Warren, S. G., and Tuttle, E.: Atmospheric ice crystals over the Antarctic Plateau in winter, Journal of Applied Meteorology, 42, 1391-1405, 2003. 